\title{
The Legal Protection of Agricultural Land Sustainable Food in Mining Coal Area of East Kalimantan
}

\author{
Haris Retno Susmiyati ${ }^{1,}{ }^{*}$, Rahmawati Al-Hidayah ${ }^{2}$ \\ ${ }^{1,2}$ Faculty of Law Mulawarman University, Samarinda, Indonesia \\ *e-mail: harisretno@fh.unmul.ac.id
}

\begin{abstract}
The effort of fulfillment over people's food is a constitutional obligation of the State. The development of an increasingly large population can threaten the existence of the tropical wet forest area when opening the land needs of food became imperative. As was the case in East Kalimantan, the area of food land is diminishing because over the function of the land are massive for coal mining and palm oil plantations. This will bring up the feared conditions insistence to open forest areas to agricultural land of food. The Central Government has the authority to make the national policy while the local government is based on the provisions of Division of the authority of Government, have the authority to make policies related to land protection food crop sector ongoing in the area. This article would like to know (1) How is the legal content in the regulation regarding the protection of sustainable food crop lands at the national level; and (2) how is regional can make a regulation of the protection sustainable food crop lands. The method is used the legal research of normative, as well as by the method of analysis is analytic descriptive. Based on the results of the study it was concluded that the regulation of sustainable food crops land protection at the national level has been set in full, but the content of legal protection, there is a weakness in political designation, which allows agricultural lands sustainable food converted as long as there is not determination as a sustainable agricultural lands. In other words, the provision in The Law No 41 Of 2009 On The Protection Of Land For Sustainable Food Plantation, but in substance precisely open up opportunities for the occurrence over the function of the land. there is a regulation on the region level regarding legal protection one of them the Regional Regulation No 1 Of 2013 On The Protection Of Sustainable Agricultural Lands, but contain elements of weakness that requires a determination of the agricultural lands before protection While official functionary who is not determination agricultural location does not get strict sanctions. This is a weakness for the agricultural land which has not been established, although physically it is the agricultural land of food, but because there is no designation then will not be affordable by the regulation of the area.
\end{abstract}

Keywords: Land, Law, Agriculture, Natural Resource, Mining, Coal, Sustainable, Protection. 


\section{INTRODUCTION}

Indonesia is a country that has abundant natural wealth in all sectors, such as mining, forestry, fisheries, plantations and agriculture, which are spread throughout the provinces and districts/cities. The wealth of natural resources should be a guarantee for the welfare and prosperity of the people. Constitutionally this guarantee is reflected in article 33 paragraph (3) of the Constitution of the Republic of Indonesia.

Extractive industries (mining and plantations) are industries that require large-scale land and industrial activities can certainly change the landscape. The economic policies of countries that prioritize extractive resource sectors have the consequence of the need for extensive land allocation, even to food areas, so that agricultural land as the main pillar of food security will be threatened if there is no guarantee of protection.

This thought was confirmed when the Government issued Law Number 41 of 2009 concerning Protection of Sustainable Food Agricultural Land (hereinafter referred to as PLP2B Law). This PLP2B Act shows that food needs are basic human rights and are basic needs that cannot be eliminated, human life will be threatened when human life support foods are not available properly.

The consideration of the PLP2B Law realizes that there needs to be a guarantee of the provision of sustainable food agricultural land as a source of work and livelihood that is appropriate for humanity. the guarantee of the right to food is a basic right of every citizen when population growth, economic and industrial developments result in degradation, transfer of functions, and fragmentation of food agricultural land has threatened of power carrying capacity nationally in maintaining food independence, resilience and sovereignty.

The next is published government regulation to strengthen the position of the PLP2B ACT, among other things: PP No. 1 Of 2011 About the determination and control of the functions of agricultural land; PP No. 12 Of 2012 On Land Protection Incentives; PP No. 25 OF 2012 About information system of agricultural land sustainable food; regulation No. 30 Of 2012 about financing the protection of agricultural land sustainable food.

Legislation regarding the conversion of land on sustainable food agricultural land (LP2B) can only be carried out for the public interest only while the conversion land for other functions is not permitted. The regulation on incentives is intended that the government provides incentives to agricultural land affected by LP2B in the form of improvements to infrastructure and facilities as well as assistance in production inputs up 
to post-harvest, for example, price guarantees. The regulation on the LP2B information system is intended to provide direction that the determination of LP2B must be accessible or informed to the public. The regulations on financing basically explain the activities of LP2B that are funded and the funding sources ${ }^{1}$.

In the context of East Kalimantan, the guarantee of protection of sustainable food agricultural land is regulated in the regional regulation of East Kalimantan Province Number 1 of 2013 concerning the protection of sustainable food agricultural land. however as well as similar to the rules above, this regional regulation has also not been able to guarantee legal protection for sustainable food agricultural land. The problems in the paper

a. What is the content of legal protection in the regulation of sustainable food crop protection at the national level?

b. How is the East Kalimantan regional government in the tropical rainforest area of Kalimantan, making regulations for the protection of sustainable food crops.

\section{METHODS}

The method used is normative legal research, as well as with analytical descriptive analysis methods. Research on regional regulation in this study is regulation issued in the province of East Kalimantan. the selection of regulatory scope in the Province of East Kalimantan is based on the consideration of the province of East Kalimantan which is the largest coal mining exploitation area in Indonesia. East Kalimantan is also an area that relies on other regions to fulfil food needs. The existence of food crops in East Kalimantan is threatened by the conversion of land for mining exploitation and other land-based sectors.

\section{RESULT AND DISCUSSION}

\subsection{The Theories of Legal Protection}

Legal protection in the opinion of legal experts, Satjipto Raharjo is to provide protection for human rights that are harmed by others and that protection is given to the public so that they can enjoy all the rights granted by law.

\footnotetext{
${ }^{1}$ Evaluation of Implementation of Sustainable Agriculture Land Policy (LP2B), Directorate of Food and Agriculture, Ministry of National Development Planning 2015
} 
According to Philips M. Hadjon, Legal Protection is the protection of dignity, as well as the recognition of human rights that are owned by legal subjects based on the legal provisions of arbitrariness. According to Philips M. Hadjon, Legal Protection is also a collection of regulations or policy that will protect something from other things ${ }^{2}$.

In carrying out and providing legal protection, a place or container is needed in its implementation which is often referred to as a means of legal protection. Legal protection facilities are divided into two types that can be understood, as follows: ${ }^{3}$

1. Preventive Legal Protection, this legal protection is a legal subject given the opportunity to submit an objection or opinion before a government decision gets a definitive form. The aim is to prevent disputes. Preventive legal protection is very significant for government actions based on freedom of action because with the preventive legal protection the government is encouraged to be cautious in making decisions based on discretion. But in Indonesia, there is no specific regulation regarding preventive legal protection.

2. Repressive Legal Protection, repressive legal protection aims to resolve disputes or the concept of legal protection against government actions which stem from the concept of recognition and protection of human rights. according to history from the west is the birth of concepts about the recognition and protection of human rights directed to restrictions and laying down the obligations of society and government.

\subsection{Definition of Sustainable Food Agriculture Land}

On daily practice, the term of land is often equated with the term soil. The land is also defined as a physical environment consisting of climate, relief, soil, water and vegetation as well as objects above it as long as there is an influence on land use, including the results of past and present human activities such as the results of sea reclamation, vegetation clearance. ${ }^{4}$ Besides that the land has a similar understanding with before that the understanding of land is: An area on the surface of the earth with certain properties which include the biosphere, atmosphere, soil, layers of geology, hydrology, plant and animal populations and the results of past and present human activities, to a certain extent these

\footnotetext{
${ }^{2}$ http://tesishukum.com/-protection-legal-sense - according to the experts/

${ }^{3}$ F.2

${ }^{4}$ Arsyad, 1989. http://infodanpengertian.blogspot.co.id/2016/02/pengertian-lahan-menurut-paraahli.html\#
} 
characteristics have a significant influence on the function of land by humans in the present and the future. ${ }^{5}$ Based on this understanding, the land is equated with soil.

in general, the type of land for food crops consists of wetlands and dry land. Wetlands are areas where the soil is saturated with water, either permanent or seasonal. Understanding Agriculture Dry land is land that can be used for agricultural business using limited water and usually only expects from rainfall or waits for rain.

Based on the provisions of article 1 paragraph 1 of the PLP2B Act, " Land is a part of the mainland the earth's surface as a physical environment which includes the land and all the factors that influence its use such as climate, relief, geological aspects, and hydrology that are formed naturally or due to human influence."

Definition of Food according to Government Regulation Number 68 of 2002 concerning Food Crops Article 1 paragraph 2 is everything that comes from biological sources and water, whether processed or not processed intended as food or drinks for human consumption, including food additives, food raw materials and other materials used in the process of preparing, processing and making food or drinks. Sustainable Food Agriculture Land is a field of agricultural land that is determined to be protected and developed consistently in order to produce staple food for national independence, resilience and food sovereignty.

\subsection{Analysis of Legal Protection of Sustainable Food Agricultural Land in National Regulation}

National regulations that specifically regulate the protection of sustainable food agricultural land specifically have only been regulated through the PLP2B Law. Before 2009 there were no regulations specifically regulating it, even though the development of extractive industries or land-based industries, namely mining and plantations that would change the landscape in its operations, had been carried out since the new order of 1967 until now.

Protection of Sustainable Food Farming Land in Article 1 (5) of the PLP2B Law is defined as a system and process in planning and establishing, developing, utilizing and fostering, controlling, and monitoring food crops and their areas sustainably.

5 Sitorus, 1989. f.4

Pattimura Law Journal Vol.5 Issue 1 September $2020 \mid 40$

DOI: $10.47268 /$ palau.v5i1.478 
Protection of Sustainable Food Agriculture Land according to article 3 of the PLP2B Law, held with the aim of:

a. protect areas and food crops sustainably;

b. guarantee the availability of sustainable food agricultural land;

c. realize independence, resilience and food sovereignty;

d. protect ownership of farmer food owned by farmers;

e. increasing prosperity and welfare of farmers and the community;

f. increasing the protection and empowerment of farmers;

g. increase the provision of employment for a decent life;

h. maintain ecological balance; and

i. realizing agricultural revitalization.

The substance of the protection to sustainable food crops is also regulated in Government Regulation Number 68 of 2002 concerning Food Crops, article 2 paragraph 2 (e) "To realize food supply is carried out by maintaining and developing the productive land." Elucidation of Letter e in the provision that what is meant by productive land is land that receives water sources, especially those originating from technical irrigation.

The problem that arises in the regulation of the protection of sustainable food agricultural land is the first: relating to the political establishment which is an order from the PLP2B Law. This is regulated in article 1 (3) of the PLP2B Act, Sustainable Food Agriculture Land is a field of agricultural land that is determined to be protected and developed consistently to produce staple food for national independence, resilience and food sovereignty. Before the determination of LP2B, what must be done is to determine the LP2B area. The authority to stipulate based on Article 23 of the PLP2B Law The Establishment of Nationally Sustainable Food Agriculture Areas is regulated in a Government Regulation concerning the National Spatial Plan. Whereas for the Province, the Establishment of the Sustainable Food Agriculture Zone of the province is regulated in the Regional Regulation concerning the provincial spatial planning. Counties or cities, the determination of the area of sustainable food Farm counties/cities arranged in local regulations regarding spatial plans of counties/cities.

Based on these provisions, it can be interpreted that to be able to be referred to as sustainable food agricultural land, the field of agricultural land have to through legal action " stipulation " as food agricultural land. If food agriculture land does not yet have a 
determination as a sustainable food agricultural land, accordingly this land does not include to the category of sustainable food agriculture as regulated in this law.

Based on Article 18 of the PLP2B Law, the protection of sustainable food agricultural land is carried out by stipulation:

a. sustainable food agricultural areas;

b. sustainable food agricultural land inside and outside of agricultural areas sustainable food; and

c. Sustainable farming food Reserves of land inside and outside of the area of sustainable food Farm

Article 3 of Government Regulation No. 1 of 2011 concerning the determination and conversion functions of sustainable food agricultural land. Determination of sustainable food agricultural land aims to: (a) Realize and guarantee the availability of sustainable food agricultural land; (b) Controlling the conversion of sustainable food agricultural land; (c) Realizing national independence, resilience and food sovereignty, increasing empowerment, income and welfare for farmers; (d) Providing business certainty for farmers; (e) Realizing ecological balance; (f) Prevent the disposal of agricultural infrastructure investments.

The legal policy of the PLP2B Act which requires the establishment process to contain weaknesses because of the stipulation conditions that cause not all food crops can be protected properly from a legal perspective. In addition, the length of the government process to establish areas for sustainable food crops has resulted in less agricultural land being protected.

Although criminal sanctions have been formulated explicitly in the criminal provisions of articles 72, 73 and 74 for perpetrators who cause the occurrence of expert functions in the agricultural land can be threatened with imprisonment and fines. But Weaknesses occur in political determination. The word "designation" can be interpreted as a necessity that land is not included in the classification of sustainable food agricultural land if there is no determination of the land will be a weakness if the government does not seriously establish sustainable food agricultural land. Another factor is that the determination as a sustainable food agriculture land has the potential to get a rejection from the community who consider the stipulation will limit the community's right to determine the land allotment. These obstacles must be resolved by the government. 


\subsection{Analysis of Legal Protection in the East Kalimantan Provincial Regulation Number 1 of 2013 concerning Protection of Sustainable Food Crops}

Based on Data from agriculture and food crop and horticulture department in the East Kalimantan said that agricultural land in East Kalimantan had declined by more than 4,711 hectares in the last two years in 2011 to 2012, of which 2,600 hectares were paddy fields. East Kalimantan has 201,769 hectares of rice fields, down from 2009's total area of 206,480 hectares $^{6}$. In 2016 in East Kalimantan there were 62,062 hectares of rice fields consisting of 13,225 hectares of irrigated rice fields and 48,837 hectares of rice fields without irrigation. There are also 200,558 hectares of gardens and 146,162 hectares of fields.

When comparing the plantation sector, the total plantation area in East Kalimantan in 2016 was 1,312,977 hectares with a production of 11,499,594 tons. The largest portion of plant area and production is shown by oil palm plants whose production reaches $11,418,110$ tons from an area of 1,150,078 hectares with the largest production in East Kutai Regency. while Rubber Plants are plants with the second largest production in East Kalimantan. Rubber production in 2016 was 62,106 tons. $^{7}$

While in the mining sector, the East Kalimantan Provincial Government noted that the coal mining area had reached the maximum limit of 5.2 million hectares. Meanwhile, the mine was managed by 1,404 holders of mining business licenses (IUP). ${ }^{8}$

East Kalimantan's dependence on the mining sector is evidenced by the economic structure of the Province of East Kalimantan (East Kalimantan) in the fourth quarter of 2017 which is still dominantly supported the largest by mining and quarrying business fields. Of the approximately 20 businesses that shaped the economy in East Kalimantan, the mining and quarrying sector contributed the highest, reaching $46.31 \%$ for East Kalimantan ${ }^{9}$.

limited of food agricultural land currently while exploitation in the plantation and mining sectors continues to be carried out and even dominantly influences the economic structure in East Kalimantan so that it becomes a major problem and threat to food security.

\footnotetext{
${ }^{6} \mathrm{http}: / /$ www.korankaltim.com/efektifkan-perda-perlindungan-lahan-pertanian

${ }^{7}$ Kalimantan timur dalam angka tahun 2017

${ }^{8}$ http://www.klikbontang.com/berita-13171-luas-tambang-batu-bara-di-kaltim-capai-titikmaksimal.html diakses 19 Februari 2018

${ }^{9} \mathrm{http}: / /$ koran-sindo.com/page/news/2018-0207/5/3/Ekonomi Kaltim Kaltara Bergantung Pertambangan
} 
Regional regulations that are normatively expected to guarantee protection as if they are not functioning in the face of exploitation, need the principle of legal certainty in regulation to ensure what is a problem of protection of sustainable food agricultural land. Although it has been regulated in the Provincial Regulation of the Province of East Kalimantan Number 13 of 2016 concerning Amendments to the Regional Regulation of the Province of East Kalimantan Number 1 of 2013 concerning Protection of Sustainable Food Agricultural Land.

Article 11 paragraph (5) of the Provincial Regulation of East Kalimantan Number 1 of 2013 jo. Regional regulation Number 13 of 2016, the area of Sustainable Food Agriculture Land is set at least 1,526,926 hectares, which is spread throughout the Regency/cities in East Kalimantan. Pursuant to the provisions of paragraph 6, the determination of the location with the coordinates of Sustainable Food Agricultural Land is determined by the relevant Regency / City Regional Regulation.

However, the requirement in Regional Regulation No. 1 of 2013 is precisely not in accordance with regional regulation No. 1 of 2016 concerning the East Kalimantan Regional Spatial Plan, which only allocates around 300 thousand hectares for the area of sustainable food agriculture. This area is very lacking when compared with the provisions in Regulation No. 1 of 2013.

Regulation of Prov. East Kalimantan Number 1 of 2013 jo. Provincial Regulation of Prov. East Kalimantan Number 13 of 2016

The availability of agricultural food land is the responsibility of the regional government, this is regulated in article 17 (3) stated that the Regional Government is responsible for the availability of land for sustainable food agriculture.

Table.3

Details of the Development Plan for Mining Area in East Kalimantan

\begin{tabular}{llr}
\hline No & District/City & $\begin{array}{r}\text { Area of Mining } \\
\text { (acres) }\end{array}$ \\
\hline 1. & Paser & 276.463 \\
2. & Kutai Barat & 998.832 \\
3. & Kutai Kartanegara & 1.113 .539 \\
4. & Kutai Timur & 1.668 .163
\end{tabular}




\begin{tabular}{llr}
5. & Berau & 368.062 \\
6. & Penajam Paser Utara & 194.760 \\
7. & Balikpapan & 1.659 \\
8. & Samarinda & 50.944 \\
9. & Bontang & - \\
10. & Mahkam Ulu & 554.715 \\
\hline & Total & 5.227 .136 \\
\hline
\end{tabular}

Source: East Kalimantan Regional Regulation No. 1 of 2016 concerning spacial planing Attachment XI Cultivation Areas

Regional Regulation Number 1 of 2013 jo. Regional Regulation Number 13 of 2016, in it also regulates the control over the conversion of sustainable food agricultural land, Article 25 (1): "Regional Government protects the area of sustainable food agricultural land as stipulated in Article 11 paragraph (1)." Sustainable food agricultural land that has been stipulated as regulated in article 11 (2) "The extent of sustainable food crop land set forth in paragraph (1) is prohibited from being converted.

However, the prohibition on the conversion of sustainable food agricultural land based on article 11 paragraph (3) can be exempted if the conversion of sustainable food agricultural land by the Regional Government in the context of land acquisition for the public interests or natural disaster.

Although it is firmly stated that new functions can be implemented if replacement land is provided, it is noteworthy that replacing land with a special classification for food agriculture is not easy, because it must match the conditions of the land for food crops. While the situation in East Kalimantan the extractive industries of coal mining and largescale oil palm plantations have controlled almost all of the strategic lands in East Kalimantan. Even based on the results of the evaluation of mining permits, the area of HPH / HTI plantations exceeded the land area of East Kalimantan. This shows that the policy of protecting food agricultural land is not only influenced by specific provisions in the field of food agriculture, but also in relation to other provisions. 


\section{CONCLUSION}

The regulation of the protection of sustainable food crops at the national level has been fully regulated. however, the content of legal protection is a weakness in the politics of establishment, which allows sustainable food agricultural land to be converted as long as there is not a determination as sustainable food agricultural land.

Legal protection in regional regulation Number 1 of 2013 concerning Protection of Sustainable Food Agriculture Land is not consistently followed by the RTRW regulation which stipulates that land is not in accordance with the regulation on the protection of sustainable food agriculture land.

\section{Suggestion}

It is necessary to reformulate the political determination stipulated in Law No. 41 of 2009 to provide more legal protection in the regulation of sustainable protection of food crops at the national level.

Legal protection in the regional regulation on the protection of sustainable food crops that have been set in Regional Regulation No. 1 of 2013, should become a reference for land-based regulation in East Kalimantan

\section{ACKNOWLEDGEMENTS}

The research was financed by the islamic development bank Project Implementation Unit - Islamic Development Bank Project-Mulawarman University

\section{BIBLIOGRAPHY}

[1] E Arsyad, 1989. http://infodanpengertian.blogspot.co.id/2016/02/pengertian-lahanmenurut-para-ahli.html\#

[2] http://tesishukum.com/-protection-legal-sense - according to the experts/

[3] http://www.korankaltim.com/efektifkan-perda-perlindungan-lahan-pertanian

[4] http://www.klikbontang.com/berita-13171-luas-tambang-batu-bara-di-kaltim-capaititik-maksimal.html diakses 19 Februari 2018

[5] http://koran-sindo.com/page/news/2018-0207/5/3/Ekonomi_Kaltim_Kaltara_Bergantung_Pertambangan

[6] Statistict of East Kalimantan of 2017

[7] Valuation of Implementation of Sustainable Agriculture Land Policy (LP2B), Directorate of Food and Agriculture, Ministry of National Development Planning 2015 